\title{
THE ROLE OF THE ANAESTHESIOLOGIST IN THE MANAGEMENT OF SEVERE SYSTEMIC TETANUS ${ }^{1}$
}

\author{
D. Leroy Crandell, m.d., Luther C. Hollandsworth, M.D., \\ and Charles E. Whitcher, M.D. ${ }^{2}$
}

IN THE MANAGEMENT of severe systemic tetanus, early diagnosis is of vital importance so that treatment can be instituted promptly. After the diagnosis has been established, the primary aim is to halt the progression of the disease and to provide adequate supportive therapy during its self-limited course.

In order to arrest the progress of the disease, two main objectives must be attained. Of primary importance is the neutralization of any circulating toxin before it can combine with the central nervous system and produce further effects. This is accomplished by the intravenous and intramuscular administration of adequate doses of tetanus antitoxin. The second main objective is to eliminate the focus of infection in order to prevent the further production of toxin. In addition to surgical excision of the focus in which the tetanus organisms are living, multiplying, and producing toxin, antibiotic therapy should be employed. Penicillin is the drug of choice because the clostridial organisms are sensitive to its bactericidal action (1). Since symbiosis is usually present, streptomycin or dihydrostreptomycin, or both, also are used to increase the spectrum of antibiotic activity.

The severity of the neuromuscular manifestations of tetanus depends on the amount of toxin that combines with the central nervous system. The duration of the incubation period provides a rough index as to the subsequent intensity of the neuromuscular manifestations.

The shorter the incubation period the more severe the neuromuscular manifestations.

Adequate supportive therapy must be provided until the toxin is released from the central nervous system and excreted from the body, usually a period of two to four weeks. Supportive therapy involves the maintenance of adequate caloric intake, fluid and electrolyte balance, pulmonary ventilation, and the control of the severe reflex muscle spasms.

The control of the reflex muscle spasms with the concomitant maintenance of pulmonary ventilation is an important and difficult aspect of the management of tetanus. The majority of deaths from tetanus are due to inadequate or improper control of the reflex muscle spasms and the subsequent deleterious effects of hypoventilation. The anaesthesiologist, with his knowledge and skill in the use of muscular relaxants and the maintenance of adequate pulmonary ventilation, can be of inestimable value in the management of this aspect of tetanus (2).

Until recent years, the control of the neuromuscular manifestations of tetanus has been accomplished by the administration of massive doses of paraldehyde,

1Presented at the Annual Meeting, Canadian Anaesthetısts' Society, June 23-25, 1958.

2From the Department of Anesthesiology, Bowman Gray School of Medicine, Wake Forest College, and the North Carolna Baptıst Hospital, Winstori-Salem, N C. 
chloral hydrate, avertin, opiates, bromides, or barbiturates. The use of such massive doses of these central nervous system depressants is not only contrary to basic pharmacological principles but detrimental to the maintenance of normal cardiovascular and respiratory physiology. A balance between central depression and suppression of muscle spasm is hard to achieve. Adequate control of the severe muscle spasms is only accomplished by subjecting the patient to the hazards of respiratory and cardiovascular depression. The added insult of hypoxia and hypercarbia on a central nervous system that is already burdened by the deleterious effects of a neurogenic toxin may prove disastrous.

The advent of drugs which block neuromuscular transmission resulted in their extensive use in the treatment of tetanus. As a whole, the results with neuromuscular blocking agents have been disappointing (3), largely owing to their bref action and the inability to produce muscular relaxation without respiratory paralysis. There is a narrow margin of safety between the relaxing dose and the completely paralysing dose.

Recently, Ibsen and Lassen have introduced a new concept in the treatment of severe systemic tetanus (4). This involves the use of fundamental principles of ana"esthesiology in the production and management of respiratory paralysis. The concept evolved from the experience of Lassen in applying anaesthesiological principles to the management of bulbospinal poliomyelitis during the epidemic in Copenhagen un 1952 (5). The subsequent decrease in mortality proved its value in the management of bulbospinal polionyelitis.

Tetanus differs from bulbospinal poliomyelitis in that muscular rigidity instead of flaccidity is present. The flaccid respiratory muscles of the patient with acute bulbospinal poliomyelits increase thoracic compliance and facilitate the maintenance of ventilation by mechanical methods. The spastic muscles of the patient with tetanus decrease thoracic compliance and oppose the maintenance of ventilation. Therefore, the thoracic compliance of the patient with tetanus is increased by paralysing doses of muscular relaxant drugs to facilitate automatic pulmonary ventilation.

The muscle relaxants that act centrally instead of peripherally have a more specific and logical pharmacological action to recommend their use in the control of reflex muscle spasms of tetanus. These drugs act centrally by depressing polysynaptic neuronal transmission.

The monosynaptic reflex arcs are unaffected. Included in the group of central acting muscle relaxants are mephenesin, zoxazolamine, chlorzoxazone, and methocarbamol. The oldest member of the group is mepheriesin. The intravenous administration of this drug has the disadvantage that the alcohol used as a vehicle may produce intoxication and a transient relaxant action of less than ten minutes. Venous thrombosis has also been reported but is less likely when a dilute solution ( 2 per cent) is used. In addition, intravascular haemolysis with subsequent haemoglobinuria and death from renal failure has occurred (6). More recently, zoxazolamine (7), chlorzoxazone, and methocarbamol have been introduced. These drugs have a similar but more potent action, but with the exception of methocarbamol they are chemically unrelated to mephenesin. Other advantages over mephenesin are their longer duration of action, smaller dose 
requirement, less toxicity and wider margin of safety Of the newer central acting muscle relaxants methocarbamol has the advantage that it can be given intravenously in a 2.5 per cent isotonic solution. The complications following the intravenous administration of mephanesin have not been encountered with methocarbamol.

Methocarbamol (Robaxin), 3-0-methoxyphenoxy-2-hydroxypropyl-1-carbamate, was synthesized by Murphey (8) from guaiacol glyceryl ether. The skeletal muscle-relaxing properties of the parent compound were described by Ginzel $(9,10)$. The pharmacological actions of this compound were determined by Truitt and Littie (11) at the Bowman Gray School of Medicine, who demonstrated that methocarbamol produces a depression of polysynaptic pathways. There is essentially no effect on the motor nerves, muscle, myoneural junction, or the monosynaptic reflex arcs. Thus, the spasm of the striate muscles is relieved or prevented by the action of methocarbamol through depression of the central nerve pathways responsible for the reflex muscle spasm.

The pharmacological rationale for the use of the central acting muscle relaxants is explained by the pathophysiology of tetanus. It has been demonstrated that the tetanus toxin selectively affects the interneurones of polysynaptic reflex arcs in the central nervous system by suppressing inhibitory synaptic action (12). As a result, polysynaptic reflexes are exaggerated and disco-ordinated due to loss of inhibitory control. The clinical manfestation of this effect on the interneurones and the alteration in polysynaptic reflexes is a greatly exaggerated contraction of the flexor muscles and simultaneous contraction rather than relaxation of the extensor muscles. Thus, the central acting muscle relaxants appear to possess the proper pharmacological action to control the rigidity and muscle spasms characteristic of tetanus.

A sedative-relaxant regimen was formulated which proved to be satisfactory in the control of reflex muscle spasm in two cases of severe systemic tetanus (Fig. 1). This consisted of methocarbamol to suppress reflex muscle spasm and secobarbital or pentobarbital to produce psychic sedation. In addition, chlorpromazine was used to potentiate the sedative-relaxant effect. Since the degree of hypertonia varies from time to time, the intravenous route of administration proved to be a more accurate means than the oral route of assessing the doseresponse relation. Clinical observation, together with pneumotachygraphic and electromyographic studies, indicated that this combination of drugs produced the desired suppression of reflex muscle spasm without concomitant respiratory depression.

Whatever the treatment involves, the patient must be provided with adequate pulmonary ventilation. Ventilatory impairment is usually incident to sustained muscular spasm or extremely depressant drug therapy rather than the direct effect of the tetanus toxin on the neurogenic tissue. Early tracheotomy should be performed in all cases of severe systemic tetanus to eliminate the possibility of upper respiratory obstruction and to facilitate suction of secretions (12). In addition, the insertion of a Levine tube or even the performance of a gastrostomy is necessary to obviate the ever-present threat of regurgitation and aspiration.

In addition to an unobstructed airway, the adequacy of aveolar ventilation may 


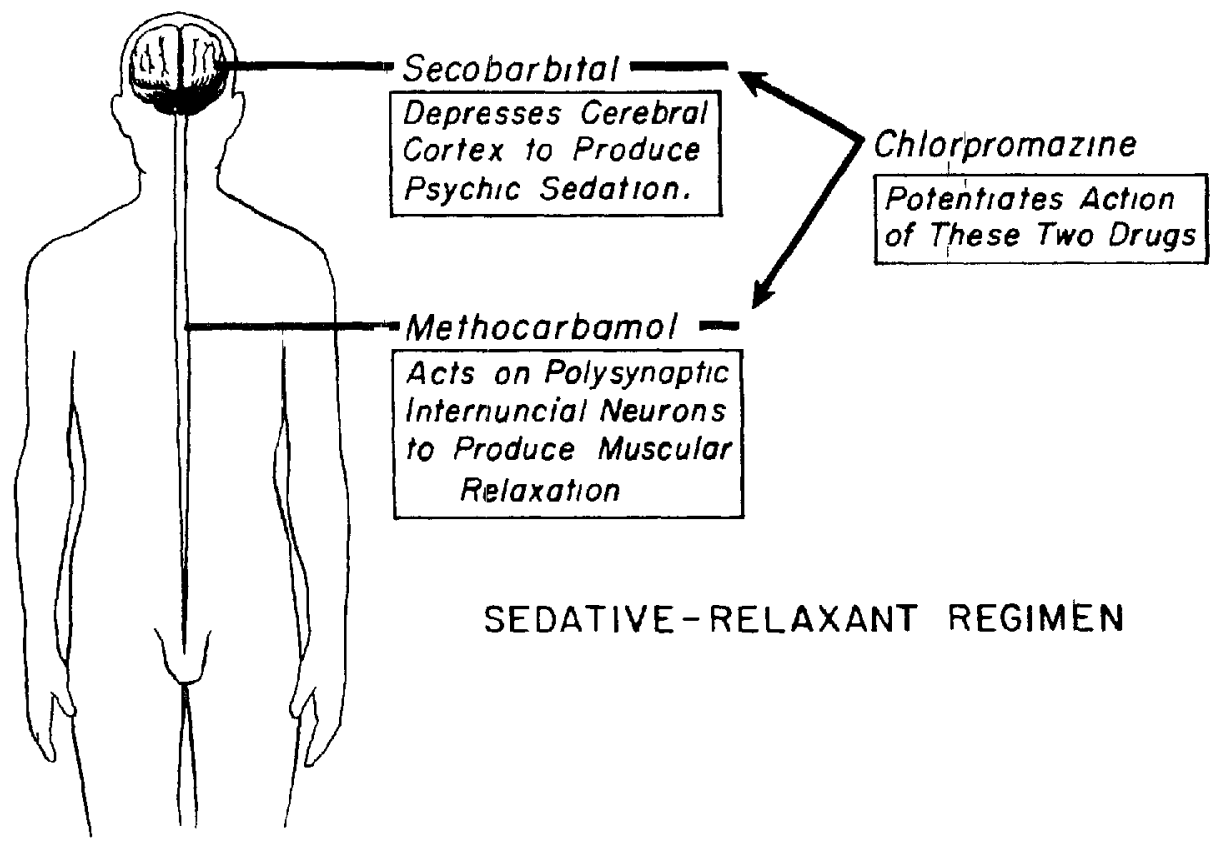

FIGURE 1

necessitate the use of a mechanical respirator to ensure proper tissue oxygenation and carbon dioxide elimination. Several methods are available but not all are practical. The tank-type respirator as it is commonly used is incompatible with a tracheotomy and greatly interferes with proper nursing and medical care. The cuirass respirator cannot provide adequate ventilation for prolonged periods to prevent carbon dioxide accumulation. Although the electrophrenic respirator preserves the normal intrathoracic pressure relations, its general use has been found to be impractical because of technical difficulties. The most effective of the mechanical respirators is one which creates intrapulmonary pressure changes to maintain ventilation. Such a machine may be coupled to an endotracheal tube with an inflatable cuff which has been inserted through the tracheostomy.

The maintenance of effective ventilation by utilizing alterations in intrapulmonary pressure requires special precautions. The intrapulmonary pressure curve must be of the type causing the least possible impairment to right-heart filling in order to avoid a reduction in cardiac output with concomitant hypotension. The period of expiration should be of longer duration than inspiration so that compensatory haemodynamic readjustments may take place during this period of phasic decrease in intrapulmonary pressure. Tolerance of positive intrapulmonary pressure is dependent on the individual patient's ability to develop and maintain an elevated central venous pressure. During the phasic decrease in intrapulmonary pressure, the elevated central venous pressure is important in permitting right-heart filling and thus contributes to the maintenance of a satisfactory cardiac output.

Thus, patients with hypovolaemia and peripheral vascular failure tolerate injudicious pressure breathing poorly, because of the inability to maintain a satisfactory central venous pressure. A system which alternates positive with negative 
pressure is less detrimental to the circulation than one which alternates positive with zero pressure. A decreased thoracic compliance is responsible for the inefficiency of ventilation in tetanus. The adverse effect a decreased thoracic compliance would have on the total volume of pulmonary ventilation is apparent. With the use of neuromuscular blocking agents, the variation in thoracic compliance enhances the problem of maintaining pulmonary ventilation by mechanical methods as compared to the patient with acute bulbospinal poliomyelitis where the thoracic compliance is increased and more constant. The mechanical ventilators require repeated readjustment owing to the variation in thoracic compliance. Without the anaesthesiologist's constant interpretation of the changes in thoracic compliance and subsequent readjustment of the ventilator, deleterious effects from excessive pressures or hypoventilation may develop.

The management of the patient with severe systemic tetanus is best carried out in an isolated room with special equipment. Constant care of these patients should be provided by trained nursing personnel under the surveillance of an anaesthesiologist. Strict observation of vital signs, of the efficiency of pulmonary ventilation, and of the status of muscle tone is important. Postural drainage, together with pharyngeal and tracheobronchial suction of secretions, must be religiously performed.

The following two case reports will illustrate the management of severe systemic tetanus by the advocated sedative-relaxant regimen. This regimen provided effective suppression of reflex muscle spasm without concomitant impairment of pulmonary ventilation.

\section{Case 1}

A 3-year-old white girl was admitted to the North Carolina Baptist Hospital with trismus and marked opisthotonus. A splinter of wood had become lodged in her right foot 7 days prior to admission. She had received no previous immunizations.

On examination, her temperature was $99.4^{\circ} \mathrm{F}$. (rectal), pulse 160 , and respiratory rate 16. She maintained an opisthotonic position with frequent generalized muscular spasms. On the ball of the right foot there was a superficial vesicle $5 \times 5 \mathrm{~cm}$. from which a 0.5-in. splinter was removed. The wound was widely excised, irrigated with hydrogen peroxide, and packed open. Tetanus antitoxin 70,000 units was administered and antibiotic therapy with pencillin and dihydrostreptomycin started. A tracheotomy was performed under nitrous oxide-Fluothane anaesthesia administered endotracheally. The patient was started on a sedative-relaxant regimen of secobarbital $25 \mathrm{mg}$., methocarbamol 200-400 mg., and chlorpromazine $10 \mathrm{mg}$., administered intravenously every $6 \mathrm{hr}$. She was maintained on thıs regimen for 17 days and her hospital course was one of continued improvement. After 17 days she was gradually removed from the sedative ${ }^{2}$ relaxant regimen. No residual neurological damaze was noted. The patient had a complete recovery and was discharged on the fortiet.. hospital day.

Case 2

A 31-year-old white man was admitted to the North Carolina Baptist Hospital 10 days after receiving a laceration to the right foot. There was no history of immunizations and he had not been in the armed services.

On admission his temperature was $100.8^{\circ} \mathrm{F}$. rectally, pulse 90 , and respirations 22. He was quite restless, with marked trismus, moderate nuchal rigidity, and slight spasm of the abdominal and sacrospinalss muscles. The right foot was described as crimson on the distal end with an open granulating wound on the tip of the distal phalanx of the great toe and a laceration o: the plantar surface of the great toe which had been 
previously sutured but was now partly open. There was a slight generalized tetanic reaction to stimulation and reflexes were generally hyperactive.

Immediately on admission 94,000 units of tetanus antitoxin were administered. An amputation of the distal portion of the right foot, including all toes, was carried out by a metatarsophalangeal disarticulation and the plantar skin and spft tissue were excised proximal to the lacerated wound opposite the great toe. A Levine tube was inserted for gastric suction and a tracheotomy performed. Antibiotic therapy with penicillin and dihydrostreptomycin was started. The patient was placed on a sedative-relaxant regimen consistmg of sodium jentobarbital $150 \mathrm{mg}$. and methocarbamol $6.0 \mathrm{gm}$,, instilled through a gastric tube every $\mathrm{C} \mathrm{hr}$.

On the twenty-fifth hospital day a surfical revision of the amputation stump was carried out under general anaesthesia. Fol owing this, the dose of methocarbamol was reduced to $3 \mathrm{gm}$. every $6 \mathrm{hr}$. The patient showed progressive improvement and was gradually taken off the sedative-relaxant regimen. He was discharged on the thirtyseventh _ospital day with no evidence of neurological impairment.

\section{SUMMARY}

An outline of the management of severe systemic tetanus has been presented. Speciâl emphasis has been given to the control of reflex muscle spasm and to the maintenance of adequate pulmonary ventilation. A sedative-relaxant regimen consisting of secobarbital or pentobarbital, methocarbamol, and chlorpromazine administered intravenously has been advocated. The anaesthesiologist, with his knowledge of the pharmacological application of drugs and of the physiological maintenance of pulmonary ventilation, can play a vital role in the management of severe systemic tetanus.

\section{RÉSUMÉ}

Le but primordial des soins d'un tétanus grave doit viser à arrêter le progrès de la maladie. Une débridement chirurgical s'impose pour' extirper le foyer infectieux et prévenir la production de toxines. Il faut administrer par voie intraveineuse ou intramusculaire de l'antitoxine pour neutraliser les toxines en circulation avant qu'elles n'attaquent le système nerveux central. Comme thérapie antibiotique, nous suggérons la pénicilline agissant contre les organismes clostridiaux et la streptomycine ou la dihydrostreptomycine ou les deux associées pour agrandir le spectre de l'activité antibiotique.

Deuxièmement, on doit donner une thérapeutique de soutien adéquate. On doit tenir compte, de l'apport calorique, de l'équilibre des liquides et des électrolytes et la ventilation pulmonaire. Les spasmes musculaires diminuent la souplesse thoracique et entravent la ventilation, contre quoi il faut employer des médicaments myorésolutifs pour augmenter la souplesse thoracique ret aider au maintien de la ventilation pulmonaire. Ceux-ci agissent à la périphérie en bloquant la transmission neuromusculaire. Ils diminuent la marge de sécurité et ils ont une durée d'action courte: pour exemple, la d-tubocurarine, la gallamine et la succinylcholine. Ils agissent sur les centres en déprimant la transmission nerveuse polysynaptique. Mephenesin comporte des risques de thrombose veineuse, d'hémolyse massive et d'anurie possible avec une solution à $10 \%$ par voie intraveineuse. De plus faibles solutions sont moins rısquées mais aussi moirs puissantes. L'action 
est de courte durée si administrée. Zoxazolamine et Chlorzoxazone sont des médicaments plus puissants possédant une marge de sécurité plus grande. Ils peuvent être administrés par voie orale ou rectale. Il est possible de donner methocarbamol par voie intraveineuse, sans complication, en solution isotonique à $2.5 \%$. Il possède une marge de sécurité plus grande que la mephenesin et il est plus puissant. Il déprime les faisceaux polysynaptiques responsables des réflexes engendrant les spasmes musculaires sans affecter les arcs réflexes monosynaptiques.

Contre les spasmes on emploie aussi la trachéotomie précoce pour éviter l'obstruction respiratoire supérieure, un tube de Levine ou une gastrostomie pour prévenir les régurgitations et l'aspiration, et un respirateur mécanique, qui en produisant des changements de pression intrapulmonaire, peut maintenir la ventilation.

L'association de la sédation et la myorésolution est mise de l'avant dans le but de contrôler les spasmes musculaires réflexes importants. Elle est donnée par voie intraveineuse pour conserver une relation plus étroite et plus précise des doses et des réponses. Pour la sédation psychique, on suggère le secobarbital ou pentobarbital; pour supprimer les spasmes musculaires réflexes, on conseille le methocarbamol; et pour potentialiser et la sédation et la myorésolution, on donne la chlorpromazine.

A supprimer totalement le spasme musculaire réflexe sans déprịmer la respiration, on doit tenir compte de l'observation clinique, des études pneumotachygraphiques et des études électromyographiques.

A donner des soins généraux, on suggère: que le malade soit placé dans une chambre d'isolement munie d'appareils spéciaux; que des infirmières expérimentées exercent une surveillance constante sous la direction de l'anesthésiologiste; qu'on fasse une observation attentive de tous les signes vitaux; qu'on évalue strictement l'efficacité de la ventilation pulmor aire; qu'on tienne compte du tonus musculaire; qu'on place le malade en positio 1 de drainage; qu'on pratique soigneusement et à répétition des nettoyages du pharynx et de l'arbre trachéobronchique.

\section{REFERENCES}

1. Symposium on Tetanus Proc. Staff Mayo Clinuc 32:141 (1957).

2. Crandell, D ' L., \& Page, W. G The Role of the Anesthesiologist in Modern Medrcine North Carolina Med. J 18:6 (1957).

3. Adriani, J., \& Ochsner, A. Curare in the Treatment of Tetanus. J. A. M A. 141574 (1949).

4. Lassen, H. C., Bjorneboe, M., Ibsen, B; \& Neuktrch, F. Treatment of Tetanus with Curarisation, General Anesthesia, and Intratracheal Positive-Pressure Ventılation Lancet F II, 267.1040 (1954).

5. LAssen, H. C. A. The Management of Respiratory and Bulbar Paralysis in Poliomyelitis. World Health Organization, Monograph Series 26.157 (1955).

6. Wruson, P. Tetanus and the Anesthetist. Australian \& New Zealand J. Surg. 26.106, (1956).

7. Amors, W. Clinical Experiences with a New Muscle Relaxant Zoxazolamine. J. A. M. A. 160:742 (1956).

8. Murphey, R. S. Research Laboratories, A. H. Robins Co., Inc. Richmond, Va. 
9 GrnzeL, K. H. Vergleichende Untersuchung einiger antikonvulsın wurksamer Glyzerinather. Arch. f. exper. Path. u. Pharmakol. 212.331 (1951).

10. Ginzel, K. H., Leuipold-Lowenthal, H., \& Weis, W. Ueber Tierversuche mit Myocain. Wien. med. Wchaschr. 99:229 (1948).

11. Truitr, E. B., Jr., \& LrTtLE, J. M. Pharmacologic Comparison of Methocarbamol (AHR-85), Monocarbanate of 3-(0-Methoxyphenoxy)-1, 2-Propanediol with Chemically Related Interneuronal Depressant Drugs. J. Pharmacol. \& Exper. Therap. 122:239 (1958).

12 Brooks, V. B., Curtis, D. R, \& Ecçles, J. C. Mode of Action 'of Tetanus Toxin. Nature 175:120 (1955).

13. Creech, O., Woodhall, J. P., \& Ochsner, A. Tracheotomy in the Treatment of Tetanus. Surgery 27:62 (1950). 